Kutsenko Iryna. Reformation of students` educational achievements monitoring process in maritime educational institutions in 1990-1999 years of the XX century. Journal of Education, Health and Sport. 2021;11(1):297-302. eISSN 2391-8306. DOI http://dx.doi.org/10.12775/JEHS.2021.11.1.029

https://apcz.umk.pl/czasopisma/index.php/JEHS/article/view/JEHS.2021.11.1.029

https://zenodo.org/record/4891155

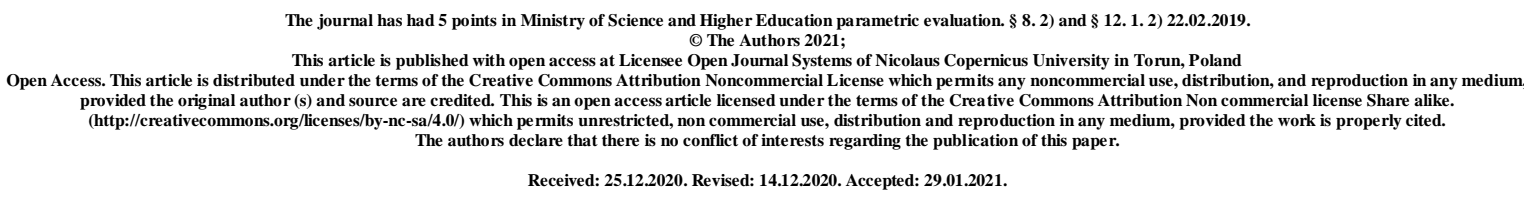

UDK 378.147

\title{
REFORMATION OF STUDENTS`EDUCATIONAL ACHIEVEMENTS MONITORING PROCESS IN MARITIME EDUCATIONAL INSTITUTIONS IN 1990-1999 YEARS of the XX CENTURY
}

\author{
Iryna Kutsenko
}

\author{
Kherson Academy of Continuing Education, Ukraine \\ Post-graduate student, \\ orcid.org/0000-0001-5347-4101
}

\begin{abstract}
The article highlights the historical improving of students` educational achievements monitoring process in maritime educational institutions in 1990-1999 of the XX century. Orders, reports, meetings of methodological associations and pedagogical meetings and other documents, the content of which is related to the educational activities of maritime educational institutions in general and monitoring, are analyzed. There was an urgent need for state monitoring of the education quality. Reforming the education of Ukraine and monitoring the academic achievements of students in maritime institutions in practice was associated with the emergence of testing and rating system.

Key words: monitoring; maritime education; resolutions of the Soviet government; educational achievements; cadets; tests; program; reports on educational work.
\end{abstract}




\title{
ОСОБЛИВОСТІ РЕФОРМУВАННЯ МОНІТОРИНГУ НАВЧАЛЬНИХ ДОСЯГНЕНЬ КУРСАНТІВ МОРСЬКИХ НАВЧАЛЬНИХ ЗАКЛАДІВ \\ У 1990-1999 РОКАX XX CT.
}

\author{
Ірина Валентинівна Куценко
}

КВНЗ «Херсонська академія неперервної освіти», Україна

\section{Анотація}

У статті висвітлені особливості впливу реформ на організацію моніторингу навчальних досягнень курсантів морських навчальних закладів у 1990-1999 роках ХХ ст. Проаналізовано накази, звіти, протоколи засідань методичних об'єднань та педагогічних зібрань та інші документи, зміст яких пов'язаний із навчальною діяльністю морських навчальних закладів в цілому та моніторингом. Аналіз історичної літератури показав, що моніторинг навчальних досягнень курсантів морських навчальних закладів був практично організований і проведений лише на самому початку 1990-х рр. в зв'язку з введенням педагогічних нововведень, відстеження ефективності реалізації яких стало обов'язковою умовою інноваційної діяльності. Реформування освіти України та моніторингу навчальних досягнень студентів морських закладів на практиці було пов'язано із появою тестів та рейтингової системи оцінювання.

Ключові слова: моніторинг; морська освіта; постанови радянського уряду; навчальні досягнення; курсанти; тести; програма; звіти про навчально-виховну роботу.

Formulation of the problem. The researched topic is relevant in the connection with the events, qualitative changes in the modern educational policy of developed countries, which have a significant impact on the domestic system of maritime education. The formation of new approaches to the processes of reforming maritime education requires a deep scientific understanding of the historical experience and the reforms of the 90s, their objective assessment and development of recommendations for the positive development of maritime education in the next XXI century.

Analysis of recent research and publications. Some aspects of the described problem were considered by a wide range of domestic and foreign scientists. Thus, studies of 
the history of pedagogy were carried out by M. Yevtukh, V. Kuzmenko, A. Savchenko, N. Slyusarenko, and others. Various aspects of the history of maritime education are considered by $\mathrm{O}$. Chorny (activities of maritime educational institutions in the south of Ukraine), $\mathrm{O}$. Timofeeva (history of maritime education in Ukraine given the social and communicative competence of future navigators), O. Chagaida (features of maritime education in Ukraine in Ukraine XX century), A. Lyashkevych (theory and practice of maritime education in the South of Ukraine in the XIX - XX centuries) and others. Archival documents are of great importance, mainly the primary materials of the State Archives of the Kherson region.

The purpose of this article is to highlight the features of improving monitoring of cadets`academic achievements in maritime educational institutions in 1990-1999 of the XX century, based on the analysis of scientific research, archival and published documents.

Research results. Some aspects of the problem were studied in the early 90's. It seems that in historiography we can distinguish three relatively independent stages, in which historians have made a significant evolution in the analysis of the main stages. First, it is the second half of the 1990s, when the work of researchers reflected the need for change in higher education and the expansion of its international relations; secondly - the stage of radical reform of the domestic higher education system, when the works of historians often met the idealization of Western educational standards; third - the period of stabilization, when the forms and methods of reforming education began to be utilized in all Ukraine in the second half of the $90 \mathrm{~s}$.

In the event of post-soviet situation, when the country underwent reforms in the economic, social, political and spiritual spheres, when the historical experience of postOctober development began to be rethought, new approaches to the analysis of policy in the field of maritime education were needed. Since then, in historiography there has been the emergence of individual studies to the level of a true generalization of the historical experience of training in Soviet society.

A. Mayorov emphasized the need to borrow some foreign principles of organization monitoring in educational process, which was an unconditional innovation in the domestic historiography of this time [3].

In the 90's, especially in the second half, there were a number of works on the problems of monitoring in education (V.I. Andreev, A.N. Mayorov, D.S. Matros, D.M. Polev, N M. Melnikov, S.E. Shishov, V.A. Kalney, etc.), which contained a theoretical basis and experience in organizing pedagogical monitoring, the use of which could be useful in solving this important scientific and practical problem. Monitoring was considered in them as a means 
of obtaining information for its further use in various areas of educational activities: teaching, education, student development, education management at different levels: regional, municipal, educational level, subject and specific pupil or student [6]. At the same time, there was an urgent need for state monitoring of the education system.

In the outlined chronological period, domestic maritime education institutions were represented by the following institutions:

- in the Kherson region - Kherson Naval School named after Lieutenant Schmidt, which was later reorganized into a naval college; private Kherson Maritime Institute;

- in the Odessa region - the Danube training and consulting center worked in the region since 1994, the Odessa Higher Maritime Engineering School, which since 1991 (Resolution № 207 of the Cabinet of Ministers of the USSR to the Odessa State Maritime Academy (hereinafter ODMA)); Mariupol Faculty of ODMA;

- in Kyiv region - Kyiv Higher Vocational School of Water Transport [5].

For the first time, monitoring in independent Ukraine began to be organized and conducted only in the early 1990s in connection with the introduction of pedagogical innovations, monitoring the effectiveness of which has become a prerequisite for innovation, always accompanied by some risk.

There was an urgent need for state monitoring of the education quality. However, all attempts to create it have not yet reached the level of their practical implementation. National systems for assessing the quality of education, compared to their organization and content with monitoring, in many European countries were established by the early 1980s.

Reports on the educational activities of the Kherson Maritime College (1992-1993) showed that the peculiarity of monitoring the cadets' academic achievements is the priority of the external side of the education system in the information and its internal features will be poorly reflected. Thus, the questionnaire for cadets was intended to collect information about cadets, their families and the schools in which they studied, cadets answered questions about the number of books in their homes, about the resources that their family has, about communication with parents in connection with studies, more than half of the questions of the questionnaire were related to reading classes: after college; use of the library; attitudes towards reading and the reasons for which the child reads. The questionnaire for teachers allowed to obtain information about the demographic characteristics of teachers, as well as some aspects of their work in general and their work in the discipline in particular. The questionnaire for parents contained questions related to classes with the child, preparation for college, etc. [1]. 
In the late 1990s, the monitoring of cadets' academic achievements in delineated maritime schools was characterized by the using the tests. Thus, the order on educational activities (1995-1996) states that the tests are developed on the basis of the principles:

- adequate coverage is checked by the content and types of educational activities;

- maximum compliance of the content with the norms of the International Maritime Organization;

- ensuring the connection of tests;

- significance is checked by the content from the development of mathematical and natural science education;

- compliance with the age characteristics of the cadets, to assess the achievements of which the test was developed;

- compliance with the requirements for mass research [2].

For the first time it was noted that indicators of learning outcomes are not the degree of mastering curricula, but the ability to apply subject knowledge and skills in situations that require the ability to generalize, reason, draw conclusions, make decisions and act productively [4].

The analysis of the literature made it possible to determine the main criteria for monitoring the academic achievements of cadets in maritime educational institutions:

- monitoring research can be conducted orally and in writing,

- during the monitoring study can be used frontal, group or individual work of study participants,

- the post-monitoring report must indicate the criteria, indicators and scales, scales used to determine the monitoring results, as well as the methodology used for their calculations,

- the report may contain tables, charts, graphs and other forms of generalization of information,

-in the case of external monitoring the use of computer equipment and its location is determined by the location of the equipment.

Conclusions and directions for further research. Thus, analyzing the archival documents we can conclude that the monitoring of educational achievements of cadets in maritime educational institutions, for the first time monitoring in independent Ukraine began to organize and conduct only in the early 1990s in connection with the introduction of pedagogical innovations. There was an urgent need for state monitoring of the quality of education. For the first time it was noted that educational achievements are not the degree of 
curriculum development, but the ability to apply subject knowledge and skills in situations that require the ability to generalize, reason, draw conclusions, make decisions, and act productively.

Prospects for further research are seen in the disclosure of the features of monitoring the academic achievements of students of maritime educational institutions at the beginning of the XXI century.

\section{References:}

1. Report on the educational activities of the Kherson maritime college, $1992-$ 1993 rr. Fund 4529. Reports about academic activities, 1992-1993 rr. Inventory 4. File. 18. Central State Historical Archive of Kherson region, Kherson.

2. Report on the educational activities of the Kherson maritime college, 1994 1995 rr. Fund 4529. Reports about academic activities, 1994-1995 rr. Inventory 7. File. 2. Central State Historical Archive of Kherson region, Kherson.

3. Maiorov A.N. Pedagogical monitoring. Moskva: Intellekt Centr, 2005. 424 p.

4. Orders and resolutions maritime college. Fund 2213. Orders and resolutions about academic activities, 1995-1996 rr. Inventory 11. File. 4. Central State Historical Archive of Kherson region, Kherson.

5. Terentieva N. Evolution of some basic concepts of university education (second half of the XX - beginning of the XXI century) Visnyk Cherkaskoho universytetu. Seriia Pedahohichni nauky. 2014, 24 (317), pp. 261-266.

6. Khodakovskyi V.F. History of maritime education in Ukraine. Kherson State maritime institute. Kherson: Oldi-plius. 2007. 